\title{
Localization and Identification of Tyrosine Phosphorylated Proteins in Adult Sprague-Dawley Rat Testis
}

\author{
Localización e identificación de proteínas de tirosina fosforilada \\ en testículos de rata Sprague-Dawley adultos
}

\author{
Amnart Chaichun $^{1}$; Supatcharee Arun ${ }^{1}$; Jaturon Burawat ${ }^{1}$; Pipatpong Kanla ${ }^{1} \&$ Sitthichai Iamsaard ${ }^{1,2}$
}

CHAICHUN, A.; ARUN, S.; BURAWAT, J.; KANLA, P. \& IAMSAARD, S. Localization and identification of tyrosine phosphorylated proteins in adult Sprague-Dawley rat testis. Int. J. Morphol., 35(4):1322-1327, 2017.

SUMMARY: Spermatogenesis is a major process in testis occurring from puberty through life span of males. The tyrosine phosphorylation is assumed to play roles in spermatogenesis because this process is important for cell proliferations, divisions, and differentiations. However, the localizations and identifications of phosphorylated proteins in testicular tissue of adult male rats are still unclear. Therefore, this study attempted to immuno-localize and identify such proteins in testicular tissues of Sprague-Dawley rats. The monoclonal anti-phosphotyrosine (clone 4G10) was used to probe tyrosine phosphorylated proteins and also to examine the expression of such proteins using immuno-Western blotting in rat testis. The result showed that positive reactivity of tyrosine phosphorylated proteins was clearly observed in interstitial endocrine cells (Leydig cells), sustentocytes (Sertoli cells), spermatogonia, spermatocytes, and spermatids (round and elongated), respectively. The expressions of testicular tyrosine phosphorylated proteins were 200, 131, 93, 70, 60, and 48 kDas, respectively. In conclusion, testicular tyrosine phosphorylated proteins were localized in both germinal epithelium and interstitial endocrine cells of adult Sprague-Dawley rats.

KEY WORDS: Localization; Identification; Tyrosine phosphorylated proteins; Testis; Rats.

\section{INTRODUCTION}

Testis is known to have dual functions including sperm and testosterone hormone productions. In histology, testicular tissue can be divided into two compartments consisting of seminiferous tubular lobules and interstitial tissues. The seminiferous epithelium contains spermatogenic and sustentocytes (Sertoli cells), responsible for spermatogenesis (Junqueira \& Carneiro, 2005; Jenkins et al., 2007; Netter, 2011). In addition, the interstitial endocrine cells (Leydig cells) in interstitial tissue play role in testosterone synthesis and secretion (Junqueira \& Carneiro).

Protein tyrosine phosphorylation is a posttranslational modification that is important for the regulation and coordination of various cell proliferations, divisions, growths, and differentiations in normal and cancer cells (Hunter \& Cooper, 1985; Hunter, 1987; Hanks et al., 1988; Ullrich \& Schlessinger, 1990; Sukhorum \& Iamsaard, 2017; Arun et al., 2016a,b). Indeed, protein tyrosine phosphorylation is required for sperm capacitation and acrosome reaction in successful fertilization process (Kopf \& Gerton, 1991; Yanagimachi, 1994; Visconti \& Kopf, 1998; Stival et al.,
2016). In testis, tyrosine phosphorylation is assumed to have the roles in spermatogenesis and testosterone synthesis because these proteins have been localized in the sustentocytes and elongated spermatids (Arad-Dann et al., 1993; Iamsaard et al., 2014; Sukhorum \& Iamsaard, 2017). However, the localizations and identifications of phosphorylated proteins in testicular tissue need to be further elucidated. Therefore, this investigation attempted to demonstrate cellular immunolocalization and expression patterns of tyrosine phosphorylated proteins in both germinal epithelium and interstitial tissues of Sprague-Dawley rats.

\section{MATERIAL AND METHOD}

Animals. Six adult male Sprague-Dawley rats (180-200 g) were purchased from the National Laboratory Animal Center, Mahidol University, Thailand and transferred to the Northeast Laboratory Animal Center, Khon Kaen University, Thailand. All rats were housed under standard environmental

\footnotetext{
${ }^{1}$ Department of Anatomy, Faculty of Medicine, Khon Kaen University, 123 Mittaparb Road, Maung, District, Khon Kaen, 40002 , Thailand. ${ }^{2}$ Center for Research and Development of Herbal Health Product, Faculty of Pharmaceutical Sciences, Mittaparb Road, Khon Kaen, 40002, Thailand.
} 
conditions and received commercial pellet food and water ad libitum. All animals were acclimatized for 7 days. This study used control animals that duly approved by Animal Ethics Committee of Khon Kaen University, based on the Ethics of Animal Experimentation of National Research Council of Thailand (ref. no. AEKKU-NLAC 10/2558). The rats were anesthetized by pentobarbital sodium before euthanasia by cervical dislocation. After rat euthanasia, the testes were dissected out. Fat pads surrounding the testes were removed before fixation. The right testis was immediately fixed in $10 \%$ phosphate buffered formalin $(\mathrm{pH}$ 7.4) to be used for immunohistochemistry and the left side was kept in $-80^{\circ} \mathrm{C}$ before immuno-Western blot analysis.

Immunohistochemistry. The fixed testicular tissues were dehydrated in graded alcohols, cleared in xylene, infiltrated, and embedded by paraffin using tissue auto-processor apparatus at Department of Pathology, Faculty of Medicine, Khon Kean University. Then, the paraffinized-testicular blocks were sectioned at $5 \mathrm{~mm}$ thickness (Semi-automatic Rotary Microtome, ERM 3100 HESTION, Australia). Testicular sections were placed on gelatin-coated glass slides and then warmed in hot air oven $\left(60^{\circ} \mathrm{C}\right)$ for $30 \mathrm{~min}$. Twelve sections (6 experiments, 6 controls) were deparaffinized in xylene and rehydrated in serial alcohols. For antigen retrieval, the sections were soaked in citrate buffer $(10 \mathrm{mM}$ citric acid, $0.05 \%$ Tween-20, pH 6.0) and heated using microwave at $95^{\circ} \mathrm{C}$. Then, such slides were cooled down at room temperature (RT) and washed with PBS. In subsequent, the endogenous peroxidase activity on tissues was blocked with $30 \%$ hydrogen peroxide $\left(\mathrm{H}_{2} \mathrm{O}_{2}\right)$ for $30 \mathrm{~min}$ at RT and then washed with PBS. The non-specific proteins were blocked with $5 \%$ bovine serum albumin (BSA; Millipore Co., USA) in PBS within moist chamber for $20 \mathrm{~min}$. After that, these sections ( 6 slides) were probed with monoclonal anti-phosphotyrosine (clone 4G10, 1:200 (v/v); Millipore, CO., USA) diluted in PBS. In parallels, the negative control sections (6 slides) were omitted with primary antibody. All sections were washed with PBS for 5 min and incubated with a horseradish peroxidase (HRP)-conjugated goat anti-mouse $\operatorname{IgG}(1: 300(\mathrm{v} / \mathrm{v})$; InvitrogenTM, USA) for $2 \mathrm{~h}$ within moist chamber at RT. The sections were washed and incubated with the Vector NovaRED peroxidase (HRP) substrate kit (Vector Laboratories, USA) for $20 \mathrm{~min}$ at dark room. Then, all sections were counterstained with Mayer's hematoxylin. In subsequent, the sections were washed with DW. After that, all sections were dehydrated with serial alcohols, cleared with xylene, and mounted with dibutylphthalate polystyrene xylene (DPX), respectively. Under light microscope observation, the positive or negative immunoreactivity on testicular tissue sections was photographed using a Nikon light ECLIPSE E200 microscope equipped with DXM1200 digital camera (Nikon, Japan).
Immuno-Western blot. Thawed-fresh testicular tissues were mixed with RIPA buffer (Cell Signaling Technology, Inc., USA) containing protease inhibitor cocktails (Sigma, Inc., USA). The testicular mixture was homogenized and centrifuged at $12,000 \mathrm{rpm}$ at $4{ }^{\circ} \mathrm{C}$ for $10 \mathrm{~min}$. The total protein concentrations of the testicular lysate were measured by using NanoDrop ND-1000 Spectrophotometer (NanoDrop Technologies, Inc., USA) at absorbance $280 \mathrm{~nm}$. For determination of the protein profiles, the testicular proteins $(80 \mu \mathrm{g})$ were loaded and separated on $10 \%$ sodium dodecyl sulfate (SDS) polyacrylamide gel followed by Coomassie blue staining (SDS-PAGE). To examine the expression of testicular phosphotyrosine proteins, separated proteins on SDS gel were transferred onto nitrocellulose membrane. Subsequently, the membrane was incubated with $5 \%$ skim milk in $0.1 \%$ PBST (0.1\% Tween-20, PBS, pH 7.4) for $1 \mathrm{~h}$ to block non-specific binding proteins and incubated with monoclonal antiphosphotyrosine (clone 4G10, 1:2,000; Millipore Co., USA) at $4{ }^{\circ} \mathrm{C}$ overnight. After washing primary antibody, it was incubated with anti-mouse conjugated with HRP secondary antibody for $2 \mathrm{~h}$ and washed with $0.05 \%$ PBST before detections of tyrosine phosphorylation by using enhanced chemiluminescence (ECL) substrate under gel doct 4 (ImageQuant 400, GH Healthcare, USA). To confirm the actual reactivity of primary antibody, epidermal growth factor stimulated A413 cell lysate (EGF; Millipore CO., USA) and bovine serum albumin (BSA; Millipore CO., USA) were used as positive and negative controls, respectively.

\section{RESULTS}

Testicular sections probed with/without monoclonal phosphotyrosine antibody (4G10) are shown in Figures 1 \& 2. Compared to the negative control (Fig. 1A, B, and C), the results showed that immunoreactivity of tyrosine phosphorylated proteins seems to be positive to both germinal epithelium and interstitial tissues with three different magnifications (Fig. 1A', B', and C').

Under observation with highest magnification (100x objective lens), we found that tyrosine phosphorylated proteins are localized in both nucleus and cytoplasm of Sertoli cell as shown in Figure 2A as compared to that of control (Fig. 2A). In addition, spermatogonia and spermatids (round and elongated) are found to be specifically positive to phosphotyrosine antibody (Fig. 2B' and $\mathrm{C}^{\prime}$ ) when compared with negative control tissues (Fig. 2B and C). Moreover, we also found that immunopositive reactivity of such monoclonal antibody is strongly localized in only nucleus and cytoplasm of interstitial endocrine cells as compared to other interstitial cells (Fig. 2D') as compared to that control (Fig. 2D). 

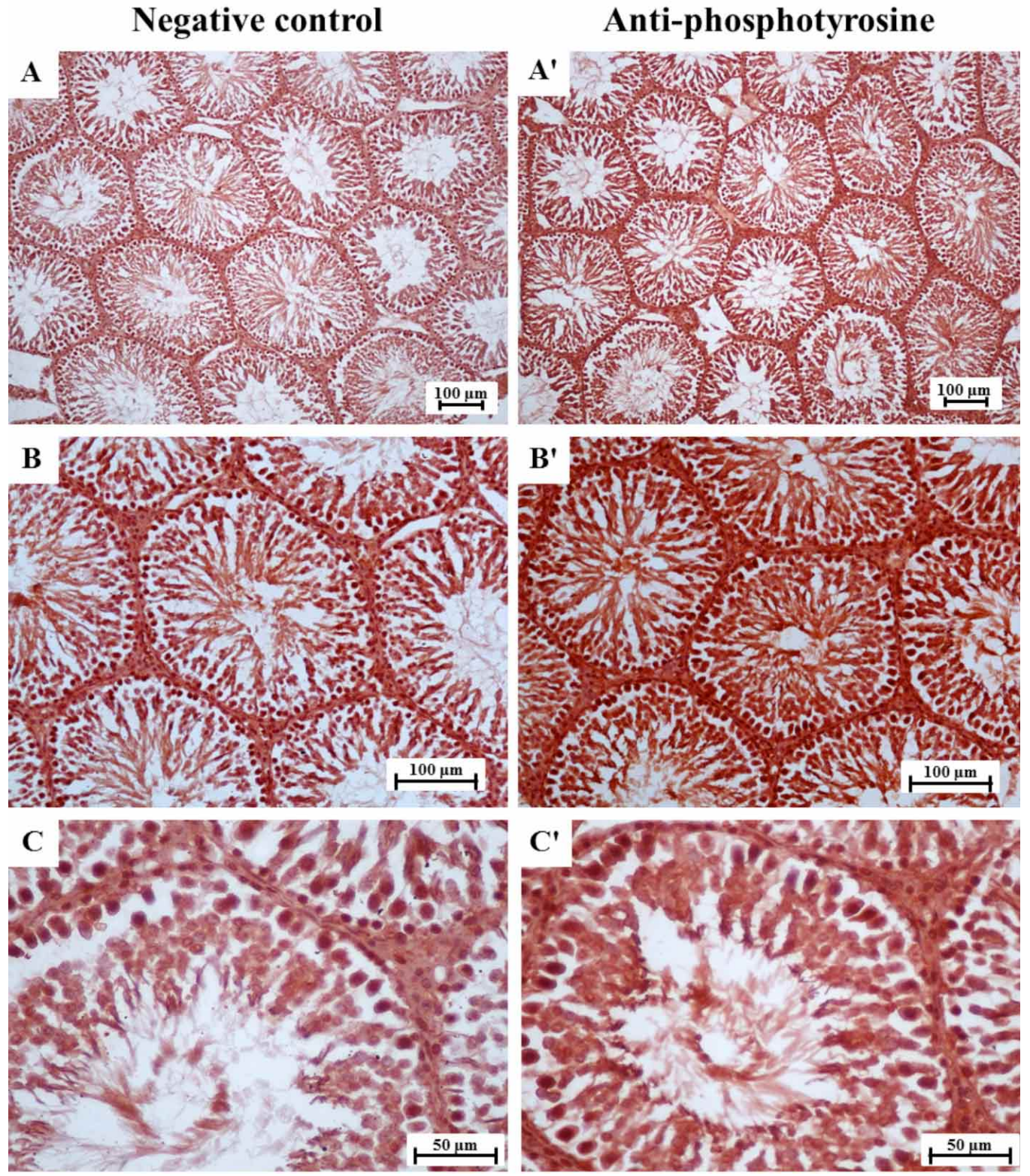

Fig. 1. Representative immunohistochemical microphotographs of rat testicular tissues against monoclonal phosphotyrosine antibody (4G10). Note: the positive immunoreactivity presents as dark red color (A', B', and $\left.\mathrm{C}^{\prime}\right)$ as compared to negative control of testicular tissue (A, B, \& C).

In addition, it was found that various proteins are presented in rat testicular lysate (Fig. 3A). Observed by immuno-Western blot, six tyrosine phosphorylated proteins were specifically probed by monoclonal-phosphotyrosine antibody (4G10) in testicular lysates of Sprague-Dawley rats (Fig. 3B). These tyrosine phosphorylated proteins are 200, 131, 93, 70, 60, and $48 \mathrm{kDas}$, respectively (Fig. 3B).

\section{DISCUSSION}

A previous study demonstrated by Arad-Dann et al. showed patterns of tyrosine residue distribution in testicular tissue of Fischer rats using an anti-phosphotyrosine monoclonal antibody (unidentified company). They stated 

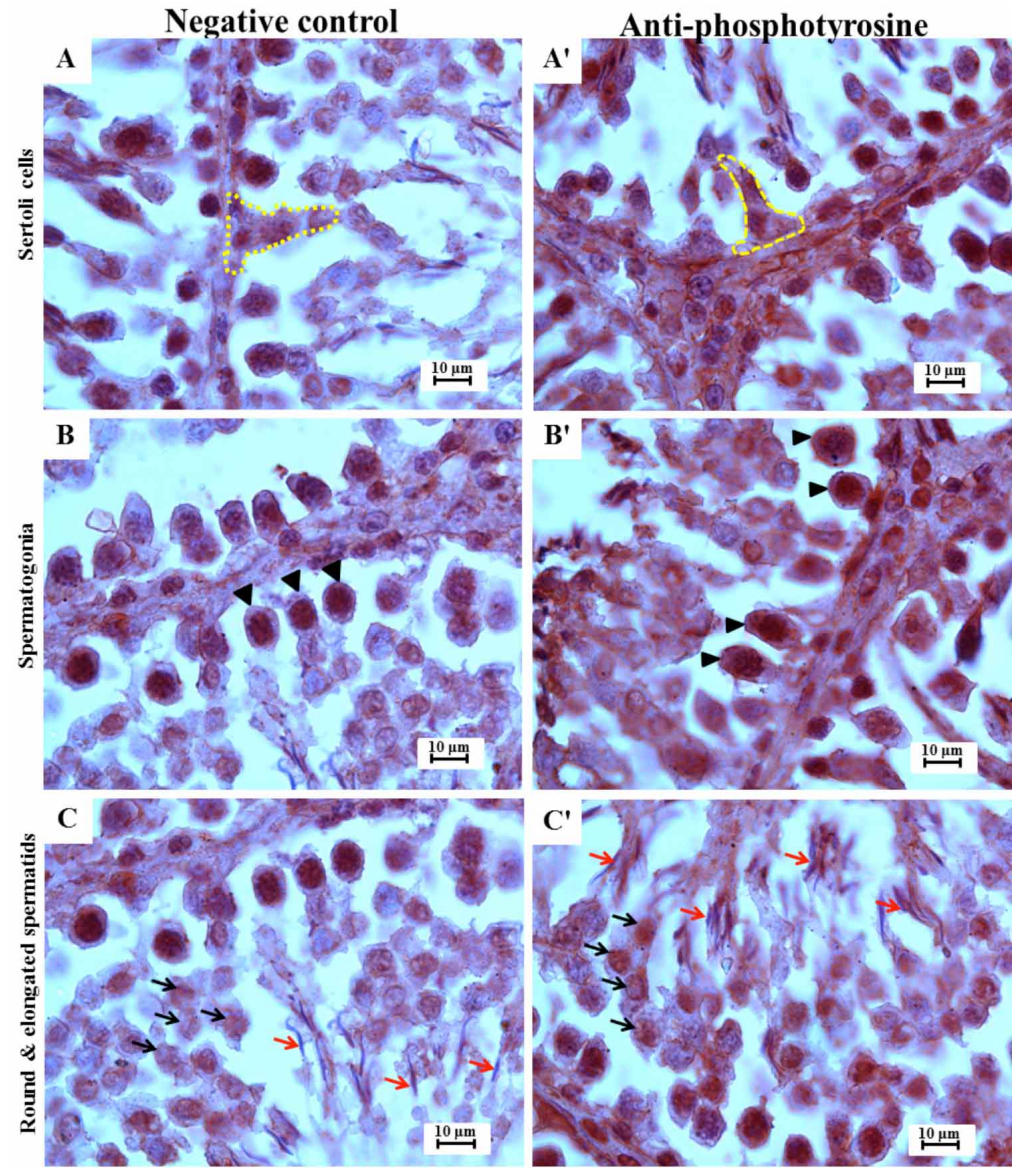

Fig. 2. Showing the positive immunolocalization of testicular phosphotyrosine in sustentocytes (Sertoli cells) (A'), spermatogonia $\left(\mathrm{B}^{\prime}\right)$, round and elongated spermatids $\left(\mathrm{C}^{\prime}\right)$, and interstitial endocrine cells (Leydig cells) (D') as compared to negative control (A, B, C, and D). Yellow line dots = Sustentocytes, black head arrows = spermatogonia.
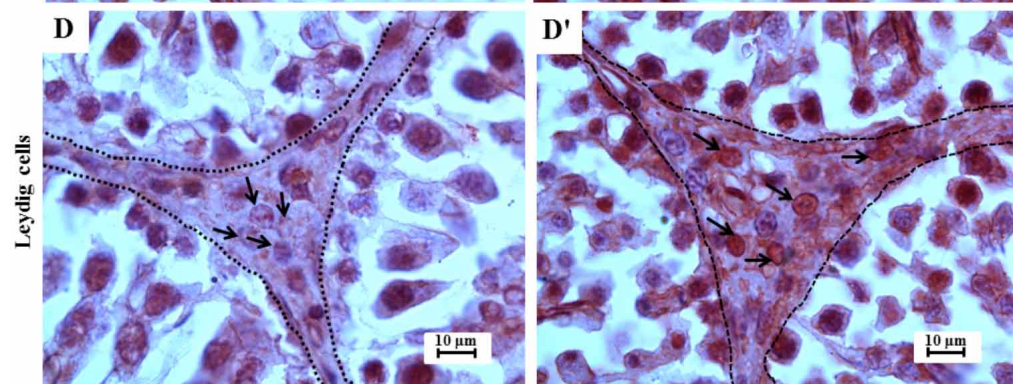

A

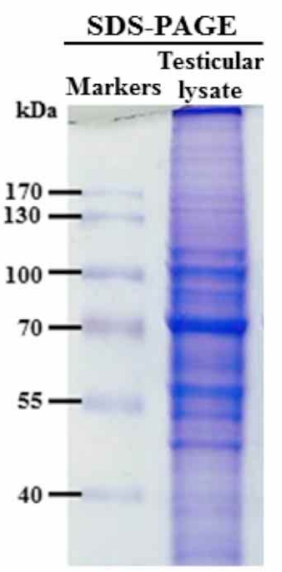

B

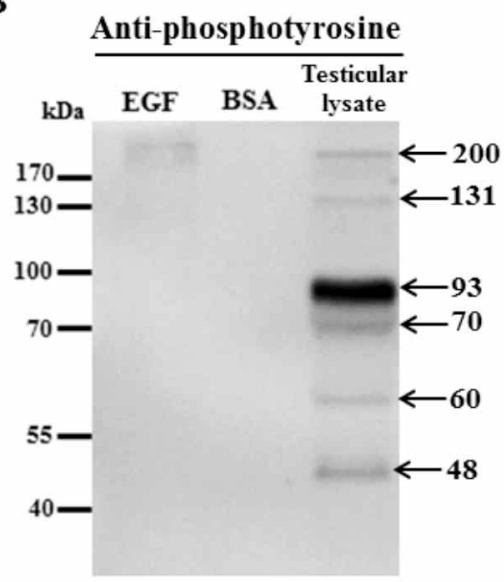

Fig. 3. Representative SDS-PAGE stained by Coomassie blue showing total testicular proteins (A) and immuno-Western blot of testicular tyrosine phosphorylated proteins of Sprague-Dawley rats (B). Bovine serum albumin (BSA) and epidermal growth factors (EGF) were used as negative and positive controls, respectively. 
that the tyrosine phosphorylated proteins were localized in only sustentocytes and elongated spermatid cells (Arad-Dann et al.). However, those immunoreactivities seemed not to be clear in term of cellular localization. Up to now, it has never seen the subcellular localization for testicular tyrosine phosphorylated proteins by using such antibody produced by Arad-Dann's research group. Recently, phosphotyrosine antibody that is specific to the tyrosine phosphorylated proteins has been produced by other companies including Millipore Co., USA. This antibody is widely used in immuno-Western blot to determine the patterns of tyrosine phosphorylated proteins in many tissues including testis as shown in previous studies (Brewis et al., 1998; Kulanand \& Shivaji, 2001; Ballester et al., 2004; Tomes et al., 2004; Iamsaard et al., 2013; 2014; Arun et al., 2016a,b; Sukhorum \& Iamsaard, 2017). However, the immunohistochemical staining patterns of tyrosine phosphorylated proteins with this antibody in testicular tissue of rats have never been reported. Interestingly, this study is the first study that showed the localization of phosphorylated proteins using a monoclonal phosphotyrosine antibody (clone 4G10, subclass IgG2b, Millipore Co., USA.) in testis of Sprague-Dawley rats. In contrast to a previous study (Arad-Dann $e t$ al.), this study clearly demonstrated that the positive immunostaining of testicular phosphotyrosine were found in interstitial endocrine cells, sustentocytes, spermatogonia, spermatocytes, and spermatids (round and elongated). Although this specific localization is still unexplained, it is possible that the different localizations between this investigation and previous study may due to the different specificity of antibodies or strain of rats. Moreover, our study showed for the first time that 200, 131, 93, 70, 60, and $48 \mathrm{kDa}$ tyrosine phosphorylated proteins were expressed in adult rat testis. To explore the structures and functions of these phosphorylated proteins, the immunoprecipitation and mass spectrometry need to be performed in further study.

\section{CONCLUSION}

This study has demonstrated that testicular tyrosine phosphorylated proteins were localized in Leydig cells, Sertoli cells, spermatogonia, spermatocytes, and spermatids of adult Sprague-Dawley rats.

\section{ACKNOWLEDGMENTS}

We would like to gratefully thank the invitation research grants from Faculty of Medicine, Khon Kaen University for financial support of this project to Amnart Chaichun (no. IN60237).
CHAICHUN, A.; ARUN, S.; BURAWAT, J.; KANLA, P. \& IAMSAARD, S. Localización e identificación de proteínas de tirosina fosforilada en testículos de rata Sprague-Dawley adultos. Int. J. Morphol., 35(4):1322-1327, 2017.

RESUMEN: La espermatogénesis es un proceso importante en los testículos que ocurre desde la pubertad a lo largo de la vida de los machos. Se supone que la fosforilación de la tirosina desempeña papeles en la espermatogénesis, debido a que este proceso es importante para las proliferaciones, divisiones y diferenciaciones celulares. Sin embargo, las localizaciones e identificaciones de proteínas fosforiladas en el tejido testicular de ratas macho adultas todavía no están claras. Por lo tanto, este estudio intentó inmuno-localizar e identificar dichas proteínas en tejidos testiculares de ratas Sprague-Dawley. La anti-fosfotirosina monoclonal (clon 4G10) se usó para sondar proteínas tirosina fosforiladas y también para examinar la expresión de tales proteínas usando inmunotransferencia Western en testículo de rata. El resultado mostró que la actividad positiva de las proteínas tirosina fosforiladas se observó claramente en endocrinocitos intersticiales (células de Leydig), sustentocitos (células de Sertoli), espermatogonias, espermatocitos y espermátidas (redondas y alargadas), respectivamente. Las expresiones de las proteínas tirosina fosforiladas testiculares fueron de 200, 131, 93, 70, 60 y $48 \mathrm{kDas}$, respectivamente. En conclusión, las proteínas tirosina fosforiladas fueron localizadas en ambos epitelios germinales y endocrinocitos intersticiales de ratas adultas Sprague-Dawley.

PALABRAS CLAVE: Localización; Identificación; Proteina tirosina fosforilada; Testículo; Rata.

\section{REFERENCES}

Arad-Dann, H.; Beller, U.; Haimovitch, R.; Gavrieli, Y. \& Ben-Sasson, S. A. Immunohistochemistry of phosphotyrosine residues: identification of distinct intracellular patterns in epithelial and steroidogenic tissues. J. Histochem. Cytochem., 41(4):513-9, 1993.

Arun, S.; Burawat, J.; Sukhorum, W.; Sumpannang, A.; Uabundit, N. \& Iamsaard, S. Changes of testicular phosphorylated proteins in response to restraint stress in male rats. J. Zhejiang Univ. Sci. B, 17(1):21-9, 2016a.

Arun, S.; Burawat, J.; Sukhorum, W.; Sampannang, A.; Maneenin, C. \& Iamsaard, S. Chronic restraint stress induces sperm acrosome reaction and changes in testicular tyrosine phosphorylated proteins in rats. Int. J. Reprod. Biomed. (Yazd), 14(7):443-52, 2016b.

Ballester, J.; Muñoz, M. C.; Dominguez, J.; Rigau, T.; Guinovart, J. J. \& Rodríguez-Gil, J. E. Insulin-dependent diabetes affects testicular function by FSH- and LH-linked mechanisms. J. Androl., 25(5):70619, 2004

Brewis, I. A.; Clayton, R.; Browes, C. E.; Martin, M.; Barratt, C. L.; Hornby, D. P. \& Moore, H. D. Tyrosine phosphorylation of a $95 \mathrm{kDa}$ protein and induction of the acrosome reaction in human spermatozoa by recombinant human zona pellucida glycoprotein 3. Mol. Hum. Reprod., 4(12):1136-44, 1998.

Hanks, S. K.; Quinn, A. M. \& Hunter, T. The protein kinase family: conserved features and deduced phylogeny of the catalytic domains. Science, 241(4861):42-52, 1988.

Hunter, T. \& Cooper, J. A. Protein-tyrosine kinases. Annu. Rev. Biochem., 54:897-930, 1985. 
CHAICHUN, A.; ARUN, S.; BURAWAT, J.; KANLA, P. \& IAMSAARD, S. Localization and identification of tyrosine phosphorylated proteins in adult Sprague-Dawley rat testis. Int. J. Morphol., 35(4):1322-1327, 2017.

Hunter, T. A thousand and one protein kinases. Cell, 50(6):823-9, 1987. Iamsaard, S.; Burawat, J.; Kanla, P.; Arun, S.; Sukhorum, W.; Sripanidkulchai, B.; Uabundit, N.; Wattathorn, J.; Hipkaeo, W.; Fongmoon, D. \& Kondo, H. Antioxidant activity and protective effect of Clitoria ternatea flower extract on testicular damage induced by ketoconazole in rats. J. Zhejiang Univ. Sci. B, 15(6):548-55, 2014.

Iamsaard, S.; Prabsattroo, T.; Sukhorum, W.; Muchimapura, S.; Srisaard, P.; Uabundit, N.; Thukhammee, W. \& Wattanathorn, J. Anethum graveolens Linn. (dill) extract enhances the mounting frequency and level of testicular tyrosine protein phosphorylation in rats. J. Zhejiang Univ. Sci. B, 14(3):247-52, 2013.

Jenkins, G. W.; Kemnitz, C. P. \& Tortora, G. J. Anatomy and Physiology. From Science to Life. Hoboken, Wiley, 2007.

Junqueira, L. C. U. \& Carneiro, J. Basic Histology. Text \& Atlas. $11^{\text {th }}$ ed. New York, McGraw-Hill, 2005.

Kopf, G. \& Gerton, G. The Mammalian Sperm Acrosome and the Acrosome Reaction. In: Wassarman, P. (Ed.). Elements of Mammalian Fertilization. Boca Raton, CRC Press, 1991. pp.154-203.

Kulanand, J. \& Shivaji, S. Capacitation-associated changes in protein tyrosine phosphorylation, hyperactivation and acrosome reaction in hamster spermatozoa. Andrologia, 33(2):95-104, 2001.

Netter, F. H. Atlas of Human Anatomy. 5th ed. New York, Kingsport, 2011. Stival, C.; Puga Molina, L. del C.; Paudel, B.; Buffone, M. G.; Visconti, P. E. \& Krapf, D. Sperm capacitation and acrosome reaction in mammalian sperm. Adv. Anat. Embryol. Cell Biol., 220:93-106, 2016.

Sukhorum, W. \& Iamsaard, S. Changes in testicular function protein and sperm acrosome status in rats treated with valproic acid. Reprod. Fertil. Dev., 29(8):1585-92, 2017.

Tomes, C. N.; Roggero, C. M.; De Blas, G.; Saling, P. M. \& Mayorga, L. S. Requirement of protein tyrosine kinase and phosphatase activities for human sperm exocytosis. Dev. Biol., 265(2):399-415, 2004.

Ullrich, A. \& Schlessinger, J. Signal transduction by receptors with tyrosine kinase activity. Cell, 61(2):203-12, 1990.

Visconti, P. E. \& Kopf, G. S. Regulation of protein phosphorylation during sperm capacitation. Biol. Reprod., 59(1):1-6, 1998.

Yanagimachi, R. Mammalian Fertilization. In: Knobil, E. (Ed.). The Physiology of Reproduction. New York, Raven Press, 1994.

\section{Corresponding author: \\ Dr. Sitthichai lamsaard \\ Department of Anatomy \\ Faculty of Medicine \\ Khon Kaen University \\ 123 Mitraparp Road \\ Amphoe Muang \\ Khon Kaen 40002 \\ THAILAND}

Email: sittia@kku.ac.th

Received: 20-05-2017

Accepted: 11-09-2017 